\title{
Quality of life and self-esteem in patients submitted to surgical treatment of skin carcinomas: long-term results
}

\author{
Paula Curitiba Maciel ${ }^{1}$ \\ Fernando Elias Martins Fonseca ${ }^{1}$
}

\author{
Joel Veiga-Filho ${ }^{1}$ \\ Lydia Masako Ferreira ${ }^{2}$
}

\author{
Marcelo Prado de Carvalho \\ Daniela Francescato Veiga ${ }^{1,2}$
}

DOI: http://dx.doi.org/10.1590/abd1806-4841.20142742

\begin{abstract}
BACKGROUND: Cancer is a multifactorial disease and skin carcinomas are the most common type of cancer. Assessing quality of life and self-esteem outcomes in skin cancer patients is important because these are indicators of the results of the treatment, translating how patients face their lives and their personal relationships. ОвјестіVE: To assess the late impact of the surgical treatment of head and/or neck skin carcinomas on quality of life and self-esteem of the patients.

MetHODS: Fifty patients with head or neck skin carcinomas were enrolled. Their age ranged between 30 and 75 years, 27 were men and 23 were women. Patients were assessed with regard to quality of life and self-esteem, preoperatively and five years postoperatively. Validated instruments were used: the MOS 36-item Short-form Health Survey (SF-36) and the Rosenberg Self-esteem/EPM-UNIFESP Scale. The Wilcoxon signed-rank test was used for the statistical analysis.

RESULTS: Twenty-two patients completed the five-year follow-up, $54.5 \%$ women and $45.5 \%$ men. Compared to the preoperative assessment, patients had an improvement in mental health $(p=0.011)$ and in self-esteem $(p=0.002)$. There was no statistical difference with regard to the other domains of the SF-36.

CONCLUSION: Patients submitted to surgical treatment of skin carcinoma improved mental health and self-esteem in the late postsurgical testing.
\end{abstract}

Keywords: Quality of life; Self concept; Skin neoplasms

\section{INTRODUCTION}

Cancer is a multifactorial disease, resulting primarily from genetic and environmental factors, as well as lifestyle. ${ }^{1}$ Among the malignant neoplasms affecting people, the most common is nonmelanoma skin cancer. Head and neck are the sites most frequently involved: $90 \%$ among men and $85 \%$ among women. The incidence of nonmelanoma skin cancer has increased over the past three decades. It is the most frequent type of cancer in Brazil, affecting about $0.06 \%$ of the population..$^{2-5}$

Malignant skin neoplasms can be basically divided into two groups: melanoma and nonmelanoma. The latter consists mainly of basal cell carcinomas and squamous cell carcinomas. Basal cell carcinoma usually tends to growth slowly and metastases are very uncommon. Squamous cell carcinoma is often more aggressive than basal cell carcinoma, with higher chance of metastases. ${ }^{6}$
In Brazil, skin carcinoma is the most frequent type of cancer in men in the South, Midwest and North regions, and the second most common type of cancer in the Southeast and Northeast regions. Among women, skin carcinoma is the most frequent type of cancer in all regions. In 2012, it was estimated that there were 62,680 new cases of nonmelanoma skin cancer among men and 71,490 new cases among women in Brazil. These figures represented an estimated risk of 65 new cases per 100,000 men and 71 new cases per 100,000 women.?

The World Health Organization (WHO) defines quality of life as "individuals' perception on their position in life in the context of the culture and value system in which they live and in relation to their goals, expectations, standards and concerns." Therefore, the concept of quality of life concerns not only the biomedical model, but also aspects related to health promotion, disease prevention, treatment and

\footnotetext{
Received on 03.05.2013.

Approved by the Advisory Board and accepted for publication on 04.07.2013.

* Study conducted at Universidade do Vale do Sapucaí (Univás) - Pouso Alegre (MG), Brazil.

Financial Support: None

Conflict of Interest: None 
rehabilitation in order to improve the patients' wellbeing. ${ }^{8}$

The term "quality of life" consists of a multidimensional (physical, psychological, social, and spiritual), subjective, dynamic, and bipolar concept. Currently, quality of life measures are essential to evaluate the results of cancer treatment. ${ }^{9}$

Self-esteem consists of a person's positive feelings about oneself. It is the core of people's subjective lives because it determines the way they think and behave. Thus, the analysis and measurement of selfesteem is based on individuals' social experiences. ${ }^{10}$

Having cancer nowadays does not necessarily mean that the patient is going to die because cure rates are increasingly rising. Thus, the concept of cure should not be solely based on the biological recovery, including also the patient's welfare, psychic survival, and quality of life. ${ }^{11-13}$ Therefore, the goal of the treatment of patients with skin cancer should include improvement in their quality of life and self-esteem. The objective of the present study was to evaluate the late impact of surgical treatment of skin carcinomas on patients' quality of life and self-esteem.

\section{PATIENTS AND METHODS}

The present study was approved by the Research Ethics Committee of Universidade do Vale do Sapucaí. All patients signed an informed consent form. This was a prospective, analytical, clinical study.

Fifty patients with head and neck skin carcinomas (biopsy-confirmed diagnosis), aged between 30 and 75 years were included, with no exclusion criteria regarding gender, ethnicity, educational level, and socioeconomic status. Patients with skin lesions smaller than $1 \mathrm{~cm}$ at their largest diameter, those who received a biopsy-based diagnosis other than skin carcinoma, and patients with concomitant presence of another type of neoplasia or metastases were excluded from the study.

During clinical diagnosis, patients' quality of life and self-esteem were also assessed (preoperative evaluation). All patients underwent surgical treatment at the teaching hospital of Univás in 2006. The surgeries were conducted in a surgical unit, under general or local anesthesia, and consisted of excision followed by primary closure, skin graft and/or local flaps, depending on the indication for each case.

After a five-year period, patients were reassessed at the time of their outpatient follow-up visit. Patients who did not return to the outpatient clinic were contacted at their homes. Twenty-two patients were reassessed. One patient refused to continue participating in the study; three patients had died, and 24 patients could not be reached.

Quality of life was assessed using the Brazilian version of the Medical Outcomes Study 36-Item ShortForm Health Survey (SF-36). Self-esteem was evaluated using a specific instrument, the Rosenberg SelfEsteem Scale/UNIFESP-EPM. ${ }^{14,15}$ Both instruments are validated for use in Brazil.

The SF-36 consists of 36 items covering eight domains: physical functioning, physical role functioning, bodily pain, general health perceptions, vitality, social role functioning, emotional role functioning, and mental health. Each area is analyzed separately, and the scores range from 0 to 100 , where 0 represents the worst possible health state and 100 represents the best possible health state. ${ }^{14}$

The Rosenberg Self-Esteem Scale/UNIFESPEPM provides a single score, ranging from 0 to 30, and the higher the score the lower the individual's selfesteem. $^{15}$

\section{Statistical method:}

Sociodemographic and clinical data were expressed as median and interquartile range. We used the Mann-Whitney test for numerical variables and the chi-square or Fisher's exact test for categorical variables in order to compare the patient group that completed the 5-year follow-up with the patient group that did not complete the follow-up in terms of demographic and clinical variables.

The comparison between the scores on the SF-36 and the Rosenberg Self-Esteem Scale/UNIFESP-EPM at the preoperative period and late postoperative period was conducted using the Wilcoxon test. The test was performed separately for each domain of the SF-36 and the Rosenberg Self-Esteem Scale/UNIFESP-EPM.

We used the SPSS (Statistical Package for Social Sciences, Inc., Chicago, USA) version 18 to perform the statistical analysis, considering a significance level of $5 \%$.

\section{RESULTS}

The patients' age ranged between 41 and 75 years old. Their median age was 60.5 years old and the interquartile range was 22 years. All patients were Caucasian, and their skin types were as follows according to the Fitzpatrick classification: I (4\%), II (64\%), III $(22 \%)$, or IV $(10 \%) .{ }^{16}$ The most prevalent type of tumor was basal cell carcinoma $(86 \%)$, and the most frequent site was the nasal region $(46 \%)$, followed by the temporofrontal, orbital, and oral regions $(18 \%$ each). The area of the lesions ranged from 1 to $24 \mathrm{~cm}^{2}$ (median: $2 \mathrm{~cm}^{2}$ and interquartile range: $3.1 \mathrm{~cm}^{2}$ ).

Of the 22 patients who completed the study, 12 $(54.5 \%)$ were women and $10(45.5 \%)$ were men. Five $(23 \%)$ of these patients had new skin carcinomas during the follow-up period. The comparison between the patient group assessed after five years $(n=22)$ and those patients who did not complete the 
follow-up $(n=28)$ regarding demographic and clinical data is shown in table 1 . There was no statistical difference between the two patient groups considering all the variables.

The comparison between the preoperative and 5 -year postoperative times in terms of the domains of the SF-36 and the Rosenberg Self-Esteem Scale/UNIFESP-EPM are shown in table 2. There was a significant improvement in the domain mental health $(p=0.011)$. There were no significant differences in relation to the other domains of the SF-36 or the self-esteem scale.

\section{DISCUSSION}

Head and neck skin carcinomas are a common type of cancer, accounting for $80 \%$ of the nonmelanoma skin tumors affecting these regions. ${ }^{17}$ Consequences of this disease and its treatment may include physical and psychological disorders. ${ }^{9,17}$ Both the lesions and scars resulting from surgical treatment may cause different degrees of deformities, and any kind of facial disfigurement may result in anxiety, depression, and social isolation. ${ }^{18}$

TABLE 1: Comparison between the patient group reassessed after five years (Group I, n=22) and the group of patients who did not complete the follow-up (Group II, $n=28$ ) regarding demographic and clinical variables

\begin{tabular}{|c|c|c|c|}
\hline & Group I (n=22) & Group II $(n=28)$ & Group I vs. Group II \\
\hline & Median (IQR*) & Median (IQR*) & Mann-Whitney test \\
\hline Age (years) & $66.5(20.0)$ & $56.5(18.2)$ & $\mathrm{p}=0.105$ \\
\hline Lesion area $\left(\mathrm{cm}^{2}\right)$ & $1.8(3.6)$ & $2.1(2.6)$ & $\mathrm{p}=0.477$ \\
\hline Gender & n ( $\%)$ & n $(\%)$ & $\begin{array}{l}\text { Chi-square test or } \\
\text { Fisher's exact test }\end{array}$ \\
\hline Male & $10(45.5 \%)$ & $17(60.7 \%)$ & $p=0.282$ \\
\hline Female & $12(54.5 \%)$ & $11(39.3 \%)$ & \\
\hline Skin type & & & $p=0.106$ \\
\hline I - II & $18(81.8 \%)$ & $17(60.7 \%)$ & \\
\hline III - IV & $4(18.2 \%)$ & $11(39.3 \%)$ & \\
\hline Type of carcinoma & & & $p=0.638$ \\
\hline Basal cell carcinoma & $19(86.4 \%)$ & $24(85.7 \%)$ & \\
\hline Squamous cell carcinoma & $3(13.6 \%)$ & $4(14.3 \%)$ & \\
\hline Site & & & $p=0.365$ \\
\hline Nasal & $7(31.8 \%)$ & $16(57.1 \%)$ & \\
\hline Temporofrontal & $5(22.7 \%)$ & $4(14.3 \%)$ & \\
\hline Orbital & $5(22.7 \%)$ & $4(14.3 \%)$ & \\
\hline Oral & $5(22.7 \%)$ & $4(14.3 \%)$ & \\
\hline
\end{tabular}

*IQR = interquartile range

TABLE 2: Comparison between the preoperative period and the 5-year postoperative period regarding the SF-36 domains and the scores on the Rosenberg Self-Esteem Scale - UNIFESP/EPM

\begin{tabular}{|c|c|c|c|c|c|}
\hline \multirow[b]{2}{*}{ Domains } & \multicolumn{2}{|c|}{ Preoperative } & \multicolumn{2}{|c|}{ Postoperative } & \multirow[b]{2}{*}{ Wilcoxon test } \\
\hline & Median & IQR* & Median & IQR $^{*}$ & \\
\hline Physical functioning & 90 & 17.5 & 88 & 31.2 & $\mathrm{p}=0.185$ \\
\hline Physical role functioning & 100 & 68.7 & 100 & 43.7 & $p=0.546$ \\
\hline Bodily pain & 72 & 38.0 & 67 & 46.0 & $\mathrm{p}=0.816$ \\
\hline General health perceptions & 80 & 18.7 & 82 & 10.0 & $p=0.541$ \\
\hline Vitality & 75 & 25.0 & 88 & 22.5 & $\mathrm{p}=0.209$ \\
\hline Social role functioning & 100 & 22.0 & 100 & 9.7 & $p=0.843$ \\
\hline Emotional role functioning & 100 & 58.7 & 100 & 0 & $\mathrm{p}=0.134$ \\
\hline Mental health & 74 & 36.0 & 88 & 12.0 & $\mathrm{p}=0.011$ \\
\hline Self-esteem & 7 & 4.7 & 2 & 4.0 & $p=0.002$ \\
\hline
\end{tabular}

*IQR = interquartile range 
Quality of life measures are essential to evaluate the results of cancer treatment; however, quality of life instruments are not routinely used to evaluate the results of oncologic surgery. ${ }^{19}$ Currently, assessing cancer patients' quality of life is an useful tool to measure the treatment outcomes from the patients' perspective, because it makes it possible to understand how different therapeutic interventions have an influence on outcomes. ${ }^{20}$

Quality of life assessment tools have been developed and used to detect disorders related to emotional state, general physical condition, and social interaction. Such assessments make it possible to design appropriate intervention programs that may change those variables that have a negative influence in the multidisciplinary approach of cancer patients. ${ }^{17,21}$

In a study of 100 subjects, 50 patients with skin carcinoma and 50 patients without cancer, Carvalho et al. found that patients with skin carcinoma had lower self-esteem compared with the control group. These authors also found that the impact on self-esteem was higher among younger people. ${ }^{22}$

Conversely, in a study of 30 patients undergoing nasal reconstruction, mainly due to skin carcinomas, Moolenburgh et al. found that, contrary to expectations, these patients did not have low levels of self-esteem. The authors explained this finding based on the fact that self-esteem is formed in early puberty. As these patients were evaluated only in the postoperative period, there was not a parameter for comparison. However, these findings are in agreement with the high level of self-esteem shown by our patients in the late postoperative period. ${ }^{23}$

A study of 52 patients with nonmelanoma skin cancer who completed the German version of the Dermatology Life Quality Index questionnaire showed that $31 \%$ of the patients experienced moderate to strong impairment in their quality of life. Such impairment involved symptoms, emotions, daily living acti- vities, and leisure activities, whereas the disease had less impact on work and school activities. ${ }^{24}$ Similarly, our patients showed improvement in mental health and self-esteem after treatment, but there was no significant difference related to the physical domain of the SF-36.

The present study was useful to analyze the impact of the surgical treatment of head and neck skin cancer on quality of life and self-esteem of patients in the 5-year postoperative period. The long follow-up period resulted in a considerable rate of loss to followup $(56 \%)$ of the patients included in the study. Although we actively tried to contact patients, 24 patients could not be found. In addition, three patients died and one did not agree to undergo late assessment. We believe that this rate of loss to followup can be explained by the minimally invasive nature of skin carcinomas. In most cases, skin excision with adequate margins can cure the disease without the need for adjuvant treatment. Therefore, many patients do not bother to return for follow-up.

Conversely, among the patients who completed the 5-year follow-up, we found significant improvement in self-esteem and in the domain mental health in the late postoperative period, which demonstrates the negative impact of skin carcinomas on these individuals' psychological components of quality of life. Considering that there was no statistical difference between the group of 22 patients who completed the follow-up and the group of patients who were not reassessed regarding sociodemographic and clinical variables, it is possible to conclude that this sample of 22 patients is representative of the study population.

\section{CONCLUSION}

In the late postoperative period, those patients who underwent surgical treatment of skin carcinoma showed improvement in mental health and selfesteem. 


\section{REFERENCES}

1. Popim RC, Corrente JE, Marino JAG, Souza CA. Câncer de pele: uso de medidas preventivas e perfil demográfico de um grupo de risco na cidade de Botucatu. Ciênc Saúde Coletiva. 2008;13:1331-6.

2. Silveira e Silva M, Castro EK, Chem C. Quality of life and self-image in patients with head and neck câncer. Univ Psychol. 2012;11:13-23.

3. Corrêa LH, Popoaski CP, Custódio G, Gonçalves C0, Trevisol FS. Epidemiology of squamous cell carcinomas among the population attended in the city of Tubarão, Brazil, between 1999 and 2009. An Bras Dermatol. 2012;87:572-7.

4. Andrade P, Brites MM, Vieira R, Mariano A, Reis JP, Tellechea 0, et al. Epidemiology of basal cell carcinomas and squamous cell carcinomas in a Department of Dermatology: a 5 year review. An Bras Dermatol. 2012;87:212-9.

5. Souza RJ, Mattedi AP, Corrêa MP, Rezende ML, Ferreira AC. An estimate of the cost of treating non-melanoma skin cancer in the state of São Paulo, Brazil. An Bras Dermatol. 2011;86:657-62.

6. Bardini G, Lourenço D, Fissmer MC. Avaliação do conhecimento e hábitos de pacientes dermatológicos em relação ao câncer da pele. ACM Arq Catarin Med. 2012;41:56-63.

7. Inca.gob.br [Internet]. Instituto Nacional do Câncer. Coordenação Geral de Ações Estratégicas. Coordenação de Prevenção e Vigilância. Estimativa 2012: Incidência do câncer no Brasil. Rio de Janeiro: Inca; 2011. 118p [acesso 4 abr. 2013]. Disponível em: http://www1.inca.gov.br/estimativa/2012/

8. Bertan FC, Castro EK. Qualidade de vida, indicadores de ansiedade e depressão e satisfação sexual em pacientes adultos com câncer. Salud \& Sociedad. 2010;1:76-88.

9. Sawada NO, Nicolussi AC, Okino L, Cardozo FMC, Zago MMF. Avaliação da qualidade de vida de pacientes com câncer submetidos à quimioterapia. Rev Esc Enferm USP. 2009;43: 581-7.

10. Ishizuka CK. Autoestima em pacientes submetidos a blefaroplastia. Rev Bras Cir Plast. 2012; 27:31-6.

11. Amaral AV, Melo RMM, Santos NO, Lôbo CMM, Benute RG, Lúcia MCS. Qualidade de vida em mulheres mastectomizadas: marcas de uma nova identidade impressa no corpo. Psicol Hosp. 2009;7:36-54.

12. Penha MA, Santos PM, Miot HA. Dimensioning the fear of dermatologic diseases. An Bras Dermatol. 2012;87:796-9.

13. Barbato MT, Bakos L, Bakos RM, Prieb R, Andrade CD. Predictors of quality of life in patients with skin melanoma at the dermatology department of the Porto Alegre Teaching Hospital. An Bras Dermatol. 2011;86:249-56.

14. Ciconelli RM, Ferraz MB, Santos W, Meinão I, Quaresma MR. Tradução para a língua portuguesa e validação do questionário genérico de avaliação de qualidade de vida SF-36 (Brasil SF-36). Rev Bras Reumatol. 1999;39:143-50.

15. Dini GM, Quaresma MR, Ferreira LM. Translation into Portuguese, cultural adaptation and validation of the Rosenberg Self-esteem Scale. Rev Soc Bras Cir Plast. 2004;19:41-54.

16. Fitzpatrick TB. The validity and practicality of sun-reactive skin types I through VI. Arch Dermatol. 1988;124:869-71.

17. Rhee JS, Matthews BA, Neuburg M, Logan BR, Burzynski M, Nattinger AB. Validation of a quality-of-life instrument for patients with nonmelanoma skin cancer. Arch Facial Plast Surg. 2006:8:314-8.

18. Caddick J, Green L, Stephenson J, Spyrou G. The psycho-social impact of facial skin cancers. J Plast Reconstr Aesthet Surg. 2012;65:e257-9.

19. Langenhoff BS, Krabbe PF, Wobbes T, Ruers TJ. Quality of life as an outcome measure in surgical oncology. Br J Surg. 2001;88:643-52.

20. Saço LF, Paula OR, Migliorini GE, Pereira NP, Ferreira EL. Características e avaliação da qualidade de vida em um grupo de pacientes submetidos a tratamento quimioterápico. HU Rev. 2011;37:95-102.

21. Silva CB, Albuquerque V, Leite J. Qualidade de vida em pacientes portadoras de neoplasia mamária submetidas a tratamentos quimioterápicos. Rev Bras Cancerol. 2010; 56:227-36.

22. Carvalho MP, Oliveira Filho RS, Gomes HC, Veiga DF, Juliano Y, Ferreira LM. Auto-estima em pacientes com carcinomas de pele. Rev Col Bras Cir. 2007;34:361-6.

23. Moolenburgh SE, Mureau MA, Versnel SL, Duivenvoorden HJ, Hofer SO. The impact of nasal reconstruction following tumour resection on psychosocial functioning, a clinical-empirical exploration. Psychooncology. 2009;18:747-52.

24. Steinbauer J, Koller M, Kohl E, Karrer S, Landthaler M, Szeimies RM. Quality of life in health care of non-melanoma skin cancer - results of a pilot study. J Dtsch Dermatol Ges. 2011;9:129-35.

\author{
MAILING ADDRESS: \\ Daniela Francescato Veiga \\ Avenida Prefeito Tuany Toledo, 470 \\ 37550-000 - Pouso Alegre - MG \\ Brazil \\ E-mail: danielafveiga@gmail.com
}

How to cite this article: Maciel PC, Veiga-Filho J, Carvalho MP, Fonseca FEM, Ferreira LM, Veiga DF. Quality of life and self-esteem in patients submitted to surgical treatment of skin carcinomas: long-term results. An Bras Dermatol. 2014;89(4):594-8. 